\title{
KIDNEY FUNCTION AFTER LEFT RENAL VEIN LIGATION IN THE DOG
}

\author{
Guilherme Velloso Diniz, Walter José Fagundes Pereira, Ana Cristina Machado \\ Moreira, Bruno Mello Rodrigues dos Santos, Domingos André Fernandes \\ Drumond and Andy Petroianu
}

RHCFAP/3028

DINIZ GV et al. - Kidney function after left renal vein ligation in the dog. Rev. Hosp. Clín. Fac. Med. S. Paulo 56(1):1-4, 2001.

The ligature of the left renal vein is an alternative whenever this vessel is injured. The purpose of this study was to evaluate the capacity of the affluents of the left renal vein, proximal to the ligature, to maintain tissue vitality and function of the left kidney. Fifteen mongrel male dogs were divided in 3 groups of 5 dogs: Group I (control) - a laparotomy was performed, and the abdominal structures were only identified; Group II — the left renal vein was tied, close to vena cava; Group III - the same procedure as for Group II and a right nephrectomy. Blood urea nitrogen and serum creatinine levels were measured before the procedure, and every 3 days during 4 weeks in the postoperative period. Renal arteriography and an excretory urogram were performed on the animals that survived 60 days. Thereafter, or immediately after precocious death, the kidneys were removed for histological examination. All the animals of Group III died before two months (mean = $10.5+-3.2$ days), while the animals of Group II survived during that period. There was a complete exclusion of the left kidney in all dogs that underwent renal vein ligature. In the animals of Group II, the renal cortico-medullary limits could not be identified. At microscopy, the aspect was suggestive of nephrosclerosis. In the animals of Group III, the left kidney was enlarged, and a great amount of intravascular and intrapelvic blood clots were observed. At microscopy, extensive areas of necrosis, inflammatory infiltration, and hemorrhage were identified. In conclusion, the tributaries of the renal vein were not sufficient to maintain the tissue vitality and function of the left kidney after ligature of its main vein.

DESCRIPTORS: Renal Vein. Tributaries of the Renal Vein. Trauma. Nephrectomy. Renal Function.

The anatomical particularities of the renal veins permit a series of considerations when the veins are lesioned or obstructed. The left renal vein is longer than the right one, crosses the aorta anteriorly, and receives several tributaries during its course, such as the left gonadal vein, the ureteral vein, and the suprarenal vein. The left renal vein communicates with a variable number of lumbar veins and the retroaortic and prevertebral venous plexi, which may serve as possible collateral venous drainage pathways through the pericapsular path ${ }^{1}$.

On the basis of these anatomical peculiarities, Whipple (1945), Teixeira
(1967), Warren (1967), Erlik (1964), and Lázaro da Silva and Petroianu (1992) proposed splenorenal, portorenal, and mesenterorenal shunts for the treatment of portal hypertension using left renal vein anastomosis with or without ligation ${ }^{2-6}$. These surgical techniques were based on the assumption that the collateral vessels of the renal vein are responsible for the drainage of the left kidney after ligation of its main vein. Siderys and Kilman have shown in dogs that left renal vein ligation was

From the Laboratory of Experimental Surgery, Faculty of Medical Sciences, Minas Gerais. associated with high mortality $(60 \%)$, but kidney function was found to be intact in the surviving dogs ${ }^{7}$.

There are different causes for the interruption of renal blood flow, such as thrombosis of the vena cava or renal vein, trauma, ligation to facilitate access in abdominal aorta aneurysmectomy, and venous shunts ${ }^{2,8-11}$. The recommended treatment for left renal vein lesions in abdominal traumatism is primary suture. However, some authors recommend ligation when collateral circulation through the gonadal and left suprarenal veins is intact, despite postoperative complications ${ }^{1,9}$. The objective of the present study was to determine 
the functional capacity of the left kidney after left renal vein ligation.

\section{METHODS}

Fifteen male mongrel dogs were randomly divided into 3 groups of 5 animals each:

group I - control (laparotomy only) group II - left renal vein ligation group III - left renal vein ligation and right nephrectomy.

The dogs were anesthetized with an intravenous injection of pentobarbital (Thiopental®) at a dose of $10 \mathrm{mg} / \mathrm{kg}$ body weight, maintained under spontaneous respiration, and tied by the four limbs in dorsal decubitus to a surgical table for medium-sized animals. The surgical site was thoroughly disinfected with water, soap, and a $2 \%$ alcohol iodide solution. The abdomen was opened through a median incision between the xiphoid appendix and 6 $\mathrm{cm}$ below the umbilical scar, and the left renal vein and its tributaries were identified. In groups II and III, the left renal vein was ligated close to the vena cava with 3-0 silk sutures. Group III animals underwent the same procedure plus right nephrectomy by ligating the vascular pedicle and the ureter with 30 silk sutures. The muscle-aponeurosis layer was closed on a single plane with continuous 2-0 nylon sutures. The skin was closed with continuous intradermal 3-0 nylon sutures.

Plasma urea and creatinine concentrations were determined in the animals before and every 3 days after surgery. The animals that were still alive after a 60-day follow-up period underwent excretory urography and renal arteriography. These animals were then sacrificed, and their kidneys were removed and stained with hematoxylin and eosin for anatomopathological studies. The kidneys of dogs that died earlier were also analyzed histologically.

The results were compared by the
Student's $t$-test, with the level of significance set at $\mathrm{p}<0.05$.

\section{RESULTS}

All control and group II animals presented good evolution during the 60 days of postoperative follow-up. Animals of group III died before the end of this period.

Group II animals showed complete exclusion of the left kidney upon postoperative excretory urography, while the right kidney presented normal vascularization and excretion (Fig. 1). In this group, the arterial phase of arteriography was slightly delayed compared to controls, and no uptake of the contrast medium was observed in the venous phase. No variation in mean plasma urea or creatinine levels was observed after surgery for group I compared to the previous phase. Group II showed an increase in these levels during the first week, with subsequent normalization. A progressive increase in serum urea and creatinine levels was observed in group III animals until their death around the 10th postoperative day (10.5 \pm 3.2 days) (Table 1$)$.

Histologic examination did not reveal any noteworthy anomaly in group I. Group II animals showed diffuse interstitial fibrosis of the renal parenchyma accompanied by a reduction in cortical thickness and obliteration of its design, tubular atrophy, and edema. In group III, subtantial congestion with parenchymatous hemorrhage and diffuse glomerular necrosis was observed (Fig. 2A and 2B).

\section{DISCUSSION}

The present study showed important alterations in kidney morphology accompanied by functional loss after left renal vein ligation. Group III dogs with only the left kidney presented

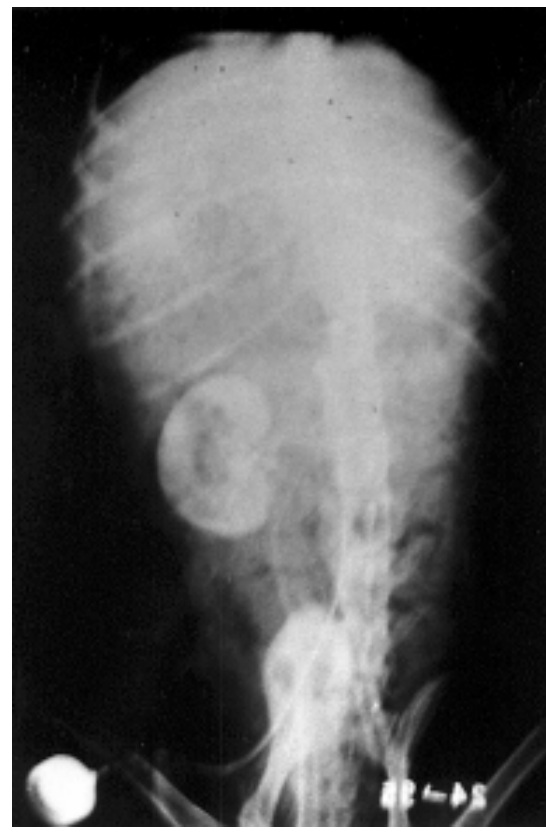

Figure 1 - Postoperative excretory urography of a group II dog, showing complete exclusion of the left kidney and maintained vascularization and excretion of the right kidney.

Table 1 - Mean plasma urea and creatinine concentration $(\mathrm{mg} / 100 \mathrm{~mL})$ of the 3 groups of dogs throughout the study.

\begin{tabular}{ccccccc}
\hline & \multicolumn{5}{c}{ Group } \\
\cline { 2 - 7 } Day & I & \multicolumn{5}{c}{ III } \\
\cline { 2 - 7 } & Urea & Creatinine & Urea & Creatinine & Urea & Creatinine \\
\hline 2 & 26.8 & 0.56 & 23.0 & 0.70 & 30.0 & 0.64 \\
4 & 26.4 & 0.66 & 47.0 & 1.24 & 68.4 & 2.52 \\
9 & 27.0 & 0.64 & 37.4 & 0.86 & 118.8 & 3.85 \\
11 & 25.0 & 0.74 & 34.0 & 1.06 & 250.0 & 10.00 \\
16 & & 0.46 & 34.6 & 0.96 & & \\
18 & & & 33.0 & 1.02 & & \\
23 & & & 35.2 & 0.94 & & \\
25 & & & 32.0 & 1.02 & & \\
30 & & & 28.6 & 0.74 & & \\
32 & & & 29.4 & 0.76 & & \\
\hline
\end{tabular}



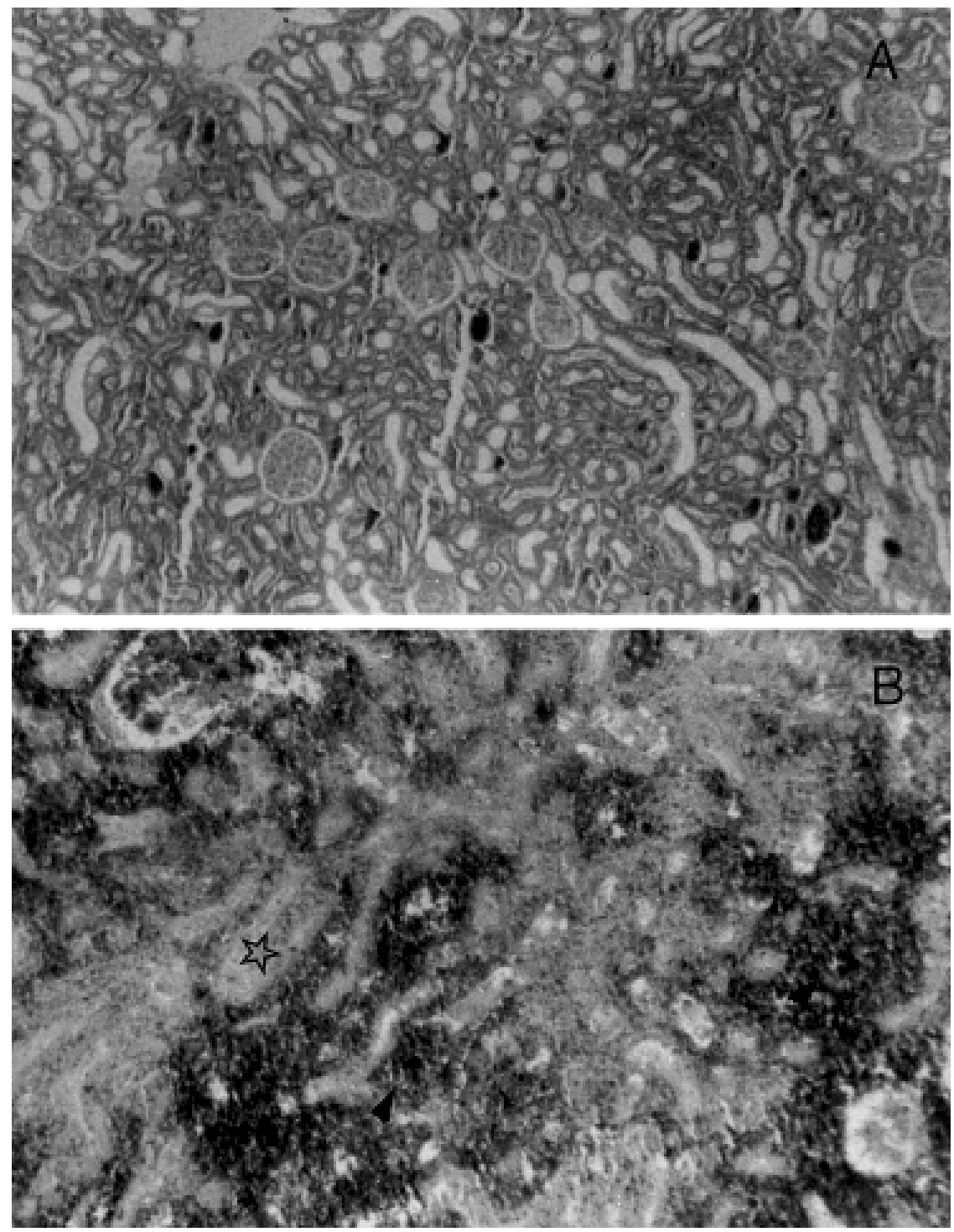

Figure 2 - Histologic kidney sections obtained from groups I and III (HE).

A, Group I (40X): Normal morphology of the left kidney.

B, Group III (100X): Areas of extensive tubular necrosis (ఓ $)$ and hemorrhage (arrows).

clear renal dysfunction as evidenced by the elevated urea and creatinine levels, leading to the death of all animals within a short period of time. These findings support the notion that the tributaries of the left renal vein are not sufficient to maintain blood drainage of the dog kidney. The maintenance of normal plasma urea and creatinine levels observed for group II may be attributed to the integrity of the function of the right kidney, since both arteriography and urography showed exclusion of the left kidney and perfect identification of the right kidney.
The present experimental findings disagree with those reported by Erlik who showed that it was possible to maintain left kidney function after ligation of the main vein in humans through its tributaries ${ }^{5}$. Experimental studies on right-nephrectomized rats also provided evidence that renal function is maintained after left renal vein ligation ${ }^{17}$.

According to the literature, an acute reduction in kidney function is generally observed after left renal vein ligation, followed by gradual improvement in renal function ${ }^{12}$. The early death of the animals is attributed to this acute dysfunction. However, histological examination revealed diffuse fibrosis of the left renal parenchyma in group II animals on the $60^{\text {th }}$ postoperative day, a fact that is not compatible with functional recovery.

Despite the anatomical similarity of renal drainage between man and dog, which would make this animal a good experimental model $^{13}$, particularities such as a higher number of collateral veins are observed in man, which may contribute to a better drainage of the left kidney distally to its tributaries after vein ligation. The safety of left renal vein ligation in man has been directly related to the well-developed collateral vein system. Alternative procedures may be autotransplantation of the kidney whose vein was lesioned or reconstruction of this structure ${ }^{16}$.

We conclude that, in the dog, kidney function or viability is not maintained after left renal vein ligation, indicating that the tributaries of this vein are not able to satisfactorily drain the kidney after the sudden interruption of renal blood flow. However, it should be noted that the response of the kidney to venous occlusion depends on the time of its installation and extension and the developed collateral circulation, as well as on whether one or both kidneys are involved and whether underlying renal disease is present ${ }^{13,14}$. Therefore, we believe it is more cautious to perform venous shunts permitting the adequate drainage of renal blood in situations where left renal vein ligation is required or in the presence of irreversible interruption of blood flow ${ }^{15}$. Nevertheless, it should be emphasized that left renal vein ligation in humans rarely compromises kidney function irreversibly in the short term due to the wealth of its tributaries $^{18}$.

\section{ACKNOWLEDGMENTS}

Research supported by $\mathrm{CNPq}$ and FAPEMIG. 
DINIZ GV e col. - Função do rim após ligadura da veia renal esquerda no cão. Rev. Hosp. Clín. Fac. Med. S. Paulo 56(1):1-4, 2001.

A ligadura da veia renal esquerda é uma alternativa operatória em presença de lesão deste vaso. O objetivo deste estudo foi avaliar a capacidade dos afluentes dessa veia, proximais à ligadura, de manter a vitalidade tecidual e a função renal. Foram estudados 15 cães mestiços, machos, divididos em três grupos de cinco cães. No Grupo I (Controle), foi realizada apenas laparotomia e identificação das estruturas. Os animais do Grupo II foram submetidos a laparotomia mediana seguida de ligadura da veia renal esquerda, próximo à veia cava. Nos animais do Grupo III, foi realizada a ligadura da veia renal esquerda, próximo à veia cava e nefrectomia direita. Determinaram-se as concentrações plasmáticas de uréia e creatinina, em todos os animais, no período pré-operatório e durante as quatro semanas pós-operatórias, a cada três dias. Nos animais que sobreviveram até o final do período de acompanhamento, realizaram-se arteriografia renal e urografia excretora. Após este período ou depois de óbito precoce, os rins foram retirados para estudo histológico. Todos os animais do Grupo III morreram antes de dois meses de seguimento ( $\mathrm{M}=10,5 \pm 3,2$ dias), enquanto os animais do Grupo II sobreviveram durante este período. Houve exclusão completa do rim esquerdo em todos os animais submetidos à ligadu- ra venosa. $\mathrm{O}$ exame anatomopatológico mostrou, no Grupo II, desaparecimento do limite corticomedular e, microscopicamente, quadro sugestivo de nefrosclerose. No Grupo III, constatouse aumento do rim esquerdo e grande quantidade de coágulos intravasculares, intrapélvicos e subcapsulares. Microscopicamente, observaram-se extensas áreas de necrose de coagulação, infiltrado inflamatório e hemorragia. Concluindo, as tributárias da veia renal esquerda foram insuficientes para manter a vitalidade tecidual e a função renal, após a ligadura de sua veia principal.

DESCRITORES: Veia renal. Afluentes da veia renal. Trauma. Nefrectomia. Função renal.

\section{REFERENCES}

1. JAMES EC, FEDDE CW, KHURI NT et al. - Division of the left renal vein. Surgery 1978; 83: 151-154.

2. WHIPPLE AO - The problem of portal hypertension in relation to the hepatosplenopathies. Ann Surg 1945; 122: 449-475.

3. TEIXEIRA ED, YU H \& BERGAN JJ - Nova técnica na cirurgia da hipertensão porta. Rev Bras Cir 1967; 53: 443-446.

4. WARREN WD, ZEPPA R \& FOMON JJ - Selective trans-splenic decompression of gastroesophageal varices by distal splenorenal shunt. Ann Surg 1967; 166: 437-455.

5. ERLIK D, BARZILAI A \& SHRAMEK A - Porto-renal shunt. Ann Surg 1964; 159: 72-78.

6. LÁZARO DA SILVA A \& PETROIANU A - Interposition mesorenal shunt for treatment of portal hypertension. Arq Bras Cir Dig 1992; 7: 16-17.

7. SIDERYS H \& KILMAN JW - The effects of acute occlusion of the renal vein in dogs. Surgery 1966; 59: 282-285.

8. WIENCEK RG \& WILSON RF - Abdominal venous injuries. Trauma 1986; 26: 771-778.

9. RASTAD J, ALMGREN BO, BOWALD S et al. - Renal complications to the left vein ligation in abdominal aortic surgery. J Cardiovasc Surg 1984; 25: 432-436.

10. BROWN MF, GRAHAN JM \& MATTOX KL - Renovascular trauma. Trauma 1980; 140: 802-805.
11. CRUMMY AB \& HIPONA FA - The Roentgen diagnosis of renal vein trombosis. Am Roentgenol 1965; 93: 898-903.

12. HARRIS JD, EHRENFELD, WK, LEE JC et al. - Experimental renal vein occlusion. Surg Gynecol Obstet 1968; 112: 555-562.

13. WITZ M, KANTAROVSKY A, MORAG B et al. - Renal vein occlusion. Urol 1996; 155: 1173-1179.

14. COX JST, JOHN HT, BANKOLE MA et al. - Collateral ciculation after renal vein occlusion. Surgery 1962; 52: 875-882.

15. KOYLE MA, KARRER FM \& MAHONEY AC - Renal-portal vein shunt for renal failure after left renal vein ligation in children. Urol 1995; 154: 1491-1494.

16. MIEDEMA BW \& STUBENBORD WT - Irreversible renal failure following right nephrectomy and left renal vein ligation. J Urol 1984; 132: 335-336.

17. KAWAMURA J, ITOH M \& YOSHIDA O - Effect of renal vein ligation with or without suprarenal inferior vena cava ligation on sodium and phosphate excretions during acute extracellular volume expansion in the rat. Invest Urol 1979; 16: 463-467.

18. MCCULLOUGH DL \& GITTES RF - Ligation of the renal vein in the solitary kidney: effects on renal function. J Urol 1975; 113: 295-298.

Received for publication on the $08 / 06 / 00$ 